Kansas State University Libraries

New Prairie Press

\title{
Leading the Transition to Active Learning Strategies and the High- Engagement Teaching Model
}

William J. Buchhorn

Butler County Community College - El Dorado, wbuchhorn@butlercc.edu

Elena Allen

Butler County Community College - El Dorado, eallen8@butlercc.edu

Follow this and additional works at: https://newprairiepress.org/accp

Part of the Community College Leadership Commons, Curriculum and Instruction Commons, Educational Leadership Commons, English Language and Literature Commons, Higher Education Administration Commons, Higher Education and Teaching Commons, and the Reading and Language Commons

(c) (1) (2)

This work is licensed under a Creative Commons Attribution-Share Alike 4.0 License.

\section{Recommended Citation}

CC BY

This Event is brought to you for free and open access by the Conferences at New Prairie Press. It has been accepted for inclusion in Academic Chairpersons Conference Proceedings by an authorized administrator of New Prairie Press. For more information, please contact cads@k-state.edu. 
300-500 Word Description of the Session: Attendees will learn how to challenge reluctant faculty in the shift toward a more student-centered learning environment while experiencing a selection of classroom delivery methods for immediate use in their own departments and their own teaching. Chairs from Butler Community College will demonstrate several AVID teaching techniques while exploring methods for implementing a department-wide shift to a new content delivery model that focuses on student success. Active learning strategies place the emphasis on what the individual student process in the classroom / course and de-emphasize the role of the teacher in favor of students working directly with the material and (collaborating) with their peers. This session will highlight presenters' experience' and Butler's successful partnership with AVID for Higher Education over the last several years and the challenges department leaders faced during the implementation of a new program that radically changed the classroom environment and shifted the emphasis away from a teacher-centered classroom toward one that led to many more students passing their freshman English and Reading courses. The session will discuss the challenges faced as the English and Reading departments underwent an evolution in the culture of their departments and inspire department chairs to undertake a similar shift in culture in their own settings. Session leaders will engage participants into active demonstration of methods for training and evaluating faculty and encouraging them to adopt many new methods of teaching quite different from the models they have used throughout their careers or experienced in their own coursework. Specific examples will be explored as case studies of implementation hurdles these two departments had to overcome are discussed as models of the types of resistance chairs might encounter as they implement any similar radical shift in department culture. The WICOR (Writing, Inquiry, Collaboration, Organization, Reading) teaching techniques demonstrated will apply to any discipline where faculty need to promote advanced reading, robust discussion, genuine inquiry, and thoughtful writing; the insights into implementation of these new techniques should prove valuable to chairs in any discipline. 